\title{
KONTRIBUSI KECERDASAN EMOSIONAL, KREATIVITAS DAN KETERLIBATAN DALAM KEGIATAN MGMP TERHADAP KETERAMPILAN MENGELOLA PEMBELAJARAN BAHASA INDONESIA PARA GURU SMA DI KABUPATEN BADUNG
}

\author{
Oleh \\ N. M. Rosini, I. M. Yudana, A.A Gede Agung \\ Program Studi Administrasi Pendidikan, Program Pascasarjana \\ Universitas Pendidikan Ganesha \\ Singaraja. Indonesia \\ e-mail: \{ made.rosini,made.yudana,gede.agung\}@pasca.undiksha.ac.id
}

\begin{abstract}
ABSTRAK
Penelitian ini bertujuan untuk mengetahui kontribusi kecerdasan emosional, kreativitas dan keterlibatan dalam kegiatan MGMP terhadap keterampilan mengelola pembelajaran Bahasa Indonesia se-Kabupaten Badung. Penelitian ini tergolong ex-post facto. Populasi penelitian ini berjumlah 30 orang dan keseluruhan menjadi sampel penelitian karena jumlah populasi di bawah 100 . Data kecerdasan emosional, kreativitas, keterlibatan guru dalam MGMP dan keterampilan mengelola pembelajaran dikumpulkan dengan kuesioner model skala likert. Data yang diperoleh dianalisis secara statistik dengan analisis regresi sederhana, analisis regresi ganda 3 prediktor dan sumbangan efektif. Temuan penelitian ini adalah; (1) terdapat kontribusi yang signifikan kecerdasan emosional terhadap keterampilan mengelola pembelajaran guru melalui persamaan garis regresi $\hat{Y}=45,510+$ $0,775 X_{1}$ dengan kontribusi sebesar $40,2 \%$. dan sumbangan efektif sebesar $3,2 \%$, (2) terdapat kontribusi yang signifikan kreativitas guru terhadap keterampilan mengelola pembelajaran guru melalui persamaan garis regresi: $\hat{Y}=21,721+0,869 X_{2}$ dengan kontribusi sebesar $62,3 \%$ dan sumbangan efektif sebesar $45,4 \%$, (3) terdapat kontribusi yang signifikan keterlibatan guru dalam MGMP guru terhadap keterampilan mengelola pembelajaran guru melalui persamaan garis regresi $\hat{\mathrm{Y}}=66,397+0,578 \mathrm{X}_{3}$ dengan kontribusi sebesar $41,5 \%$ atau sumbangan efektif sebesar $14 \%$, dan (4) secara bersama-sama terdapat kontribusi yang signifikan kecerdasan emosional, kreativitas guru, dan keterlibatan guru dalam MGMP terhadap keterampilan mengelola pembelajaran guru melalui persamaan garis regresi $\hat{Y}=15,332+0,066 X_{1}+0,673 X_{2}+0,206 X_{3}$ dengan kontribusisebesar $62,6 \%$. Dengan demikian maka ke tiga variabel tersebut dapat dijadikan predictor tingkat kecendrungan keterampilan mengelola proses pembelajaran guru SMA se-Kabupaten Badung.
\end{abstract}

Kata Kunci : kecerdasan emosional, kreativitas, keterlibatan dalam kegiatan MGMP, Keterampilan Mengelola Pembelajaran

\begin{abstract}
This study aims at discovering the contribution of emotional quotient, creativity and teachers' involvement in teachers' subject organization on teachers' skill in managing instruction process in Badung Regency. This research is ex-post facto. The population of this research is 22Indonesia language teachers and all of them were selected to be the sample because the number was lower than 100. The data of emotional intelligence, creativity, teachers' involvement in teachers' subject organization and teachers' skill in managing instruction process were collected by using questionnaire with Likert scale. The collected data were analyzed by using simple regression, multiple regression with three predictors and effective contribution. This research discovers: (1) there is a significant contribution of emotional quotient on teachers' skill in managing instruction process with regression line equation of $\hat{Y}=45,510+0,775 X_{1}$ with contribution of $40,2 \%$ and effective contribution of $3,2 \%$, (2) there is a significant contribution of creativity on teachers' skill in managing instruction process with regression line equation of $\hat{\mathrm{Y}}=21,721+0,869 \mathrm{X}_{2}$ with contribution of $62,3 \%$ and effective contribution of $45,4 \%$, (3) there is a significant contribution of teachers' involvement in teachers' subject organization on teachers' skill in managing instruction process with regression line equation of $\hat{\mathrm{Y}}$
\end{abstract}


$=66,397+0,578 X_{3}$ with contribution of $41,5 \%$ and effective contribution of $14 \%$, and (4) simultanously, there is a significant emotional quotient, creativity, andteachers' involvement in teachers' subject organization on teachers' skill in managing instruction process with regression line equationof $\hat{Y}=$ $15,332+0,066 X_{1}+0,673 X_{2}+0,206 X_{3}$ with contribution of $62,6 \%$. It can be concluded that all the independent variables can be used as predictors of the tendency of teachers' skill in managing instruction process in Badung Regency.

Keywords: pedagogical competency, working climate, working ethos, teachers' performance

\section{PENDAHULUAN}

Pengelolaan (management) adalah proses yang memberikan pengawasan pada semua hal yang terlibat dalam pelaksanaan kebijaksanaan dan pencapaian tujuan (Depdikbud, 1989). Kelas (dalam artian umum) menunjuk kepada pengertian sekelompok siswa yang ada pada waktu yang sama menerima pelajaran yang sama dari guru yang sama pula. Ini berarti, bahwa pengelolaan kelas adalah mengacu pada penciptaan suasana atau kondosi kelas yang memungkinkan peserta didik dalam kelas tersebut dapat belajar dengan efektif.

Pengelolaan kelas adalah segala usaha yang diarahkan untuk mewujudkan suasana belajar mengajar yang efektif dan menyenangkan serta dapat memotivasi siswa untuk belajar dengan baik sesuai dengan kemampuan, karena pengelolaan kelas merupakan usaha sadar, untuk mengatur kegiatan pengelolaan kelas secara sistematis. Usaha sadar itu mengarah pada penyiapan bahan pengelolaan kelas, penyiapan sarana dan alat peraga, pengaturan ruang belajar, mewujudkan situasi/kondisi pengelolaan kelas dan pengaturan waktu sehingga pengelolaan kelas berjalan dengan baik dan tercapainya tujuan pengelolaan kelas (Dirjen Dikdasmen, 1996).

Dengan pengertian tersebut dapat dikatakan bahwa guru dalam mengelola kelas harus memiliki kompetensi (kemampuan) yang dapat diklasifikasikan menjadi tiga golongan, yaitu: (1) kompetensi pribadi, (2) keterampilan mengelola pembelajaran, dan (3) kompetensi kemasyarakatan (Joni, 1992: 28).

Keterampilan mengelola pembelajaran mengisyaratkan bahwa guru harus memiliki pengetahuan yang luas dan mendalam tentang bidang studi ( subject matter) yang diajarkannya. Di samping itu, seorang guru hendaknya menguasai metodologi pengelolaan kelas dalam artian memiliki pengetahuan konsep teoritis, mampu memilih metode yang tepat, serta mampu menggunakannya dalam pengelolaan kelas. Rusyan dan Hamijaya (1992: 18-20) mengemukakan bahwa keterampilan mengelola pembelajaran mencakup: (1) mengerti dan dapat menerapkan landasan kependidikan baik filosofis, psikologis dan sebagainya; (2) mengerti dan dapat menerapkan teori belajar sesuai dengan tingkat perkembangan perilaku peserta didik; (3) mampu menangani mata pelajaran yang ditugaskan kepadanya; (4) mengerti dan dapat menerapkan metode pengelolaan kelas yang sesuai; (5) mampu menggunakan berbagai alat pengelolaan kelas dan media serta fasilitas belajar yang lain; (6) mampu melaksanakan evaluasi belajar; (7) mampu menumbuhkan kepribadian peserta didik. Lebih khusus keterampilan mengelola pembelajaran tenaga kependidikan dijabarkan menjadi : (1) menguasai bahan meliputi : (a) menguasai bahan bidang studi dan kurikulum sekolah; (b) menguasai bahan pendalaman/aplikasi bidang studi; (2) mengelola program pengelolaan kelas, meliputi; (a) merumuskan tujuan instruksional; (b) mengenal dan dapat menggunakan metode pengelolaan kelas; (c) memilih dan menyusun prosedur instruksional yang tepat; (d) melaksanakan program pengelolaan kelas, (3) mengelola kelas meliputi; (a) mengenal, memilih dan menggunakan media, (b) membuat alat-alat bantu pengelolaan kelas yang sederhana, (c) menggunakan dan mengelola laboratorium dalam rangka pengelolaan kelas; (d) mengembangkan laboratorium; (e) menggunakan perpustakaan dalam pengelolaan kelas; (f) menggunakan lingkungan sekolah latihan dan microteaching dalam PPL, (4) Menguasai landasan kependidikan, (5) mengelola interaksi pengelolaan kelas, (6) mengenal fungsi layanan dan bimbingan, meliputi mengenal fungsi program layanan dan bimbingan di sekolah, (7) mengenal dan menyelenggarakan administrasi sekolah, meliputi; (a) mengenal penyelenggarakan administrasi sekolah; (b) menyelenggarakan administrasi sekolah, (9) memahami prinsif-prinsif dan penafsiran hasil-hasil penelitian pendidikan guna kepentingan 
pengelolaan kelas, (10) memiliki sifat-sifat yang mendorong kemajuan pendidikan dan memahami peserta didik, (11) menampilkan keteladanan dan kepemimpinan dalan pengelolaan kelas, (12) mampu meneliti masalah-masalah pendidikan, (13) mengembangkan teori dan konsep dasar kependidikan, (14) merencanakan program pendidikan, (15) menerapkan berbagai keahlian bidang pendidikan, (16) menilai dan menguji proses pendidikan, (17) menguasai, melaksanakan dan menilai ilmu yang menyangkut bidang studi, (18) melaksanakan kurikulum yang berlaku, (19) membina dan mengembangkan kurikulum di sekolah dan di luar sekolah, (20) menilai dan memperbaiki kurikulum di sekolah sesuai dengan perkembangan ilmu pengetahuan dan teknologi dan kemajuan zaman, (21) memahami dan melaksanakan $k$ Terdapat 2 faktor utama yang mempengaruhi kualitas pengelolaan pembelajaran guru, faktor intern dan ekstern. Faktor intern adalah faktor yang bersumber dari dalam diri, seperti kreativitas, kecerdasan emosional, kreativitas, motivasi dan bakat. Sedangkan faktor dari luar adalah kepemimpinan kepala sekolah, iklim kerja, keterlibatan guru dalam seminar, MGMP, workshop dan kegiatan-kegiatan akademik lainnya.

Dalam konteks penelitian ini, peneliti akan menginvestigasi 2 faktor intern, kecerdasan emosional dan kreativitas guru; serta satu faktor ekstern yaitu keterlibatan guru dalam MGMP. Melalui penelitian ini diharapkan kontribusi ketiga variabel itu dapat dibuktikan secara empiris terhadap keterampilan guru mengelola proses pembelajaran dan konsep mengajar individu.

Pembatasan masalah diperlukan agar penelitian lebih terarah, terfokus dan tidak menyimpang dari sasaran pokok penelitian. Oleh karena itu, penulis memfokuskan kepada pembahasan atas masalah-masalah pokok yang dibatasi pada 4 variabel, yaitu: kecerdasan emosional guru, kreativitas guru, partisipasi guru dalam kegiatan MGMP, dan keterampilan guru mengelola proses pembelajaran.

Berdasarkan latar belakang dan identifikasi masalah, maka masalah yang akan diteliti dalam penelitian ini adalah sebagai berikut.

a. Seberapa besar kontribusi kecerdasan emosional guru terhadap keterampilan guru mengelola pembelajaran Bahasa Indonesia SMA Se Kabupaten Badung?

b. Seberapa besar kontribusi kreativitas guru terhadap keterampilan guru mengelola pembelajaran Bahasa Indonesia SMA Se Kabupaten Badung?

c. Seberapa besar kontribusi partisipasi guru dalam kegiatan MGMP terhadap keterampilan guru mengelola pembelajaran Bahasa Indonesia SMA Se Kabupaten Badung?

d. Seberapa besar kontribusi secara bersama-sama kecerdasan emosional guru, kreativitas guru dan partisipasi guru dalam kegiatan MGMP terhadap keterampilan guru mengelola pembelajaran Bahasa Indonesia SMA Se Kabupaten Badung?

\section{METODE PENELITIAN}

Rancangan penelitian ini, dengan mengambil data yang sudah ada secara empiris tanpa melakukan ekperimen terhadap variabel. Dalam penelitian ini, ketika peneliti mengadakan pengamatan terhadap variabel terikat, variabel-variabel bebasnya sudah terjadi. Sehingga dengan demikian, maka penelitian ini bersifat ex-post facto (Darmadi, 2011). Penelitian ini termasuk pendekatan kuantitatif dengan rancangan korelasional karena dalam penelitian ini mencoba mengetahui hubungan yang ada, antar variabel yang dikorelasikan. Hasil penelitian hanyalah mendeskripsikan dan menganalisis hubungan antara kecerdasan emosional guru, kreativitas guru dan partisipasi guru dalam kegiatan MGMP terhadap keterampilan mengelola pembelajaran guru Bahasa Indonesia SMA Se-Kabupaten Badung. Populasi dalam penelitian ini adalah seluruh guru-guru Bahasa Indonesia SMA Se Kabupaten Badung yang berjumlah 30 orang. Guru yang diteliti adalah guru yang berstatus PNS, kontrak dan honorer.

Variabel yang diteliti dalam penelitian ini meliputi variabel bebas (independent variable) dan variabel terikat (dependent variable). Variabel bebas $(X)$ yaitu variabel yang mempengaruhi variabel terikat. Sedangkan variabel terikat $(Y)$ adalah variabel yang dipengaruhi akibat adanya variabel bebas. 
Dalam penelitian ini, data dikumpulkan melalui data tentang kecerdasan emosional guru, kreativitas guru, partisipasi guru dalam kegiatan MGMP dan keterampilan guru mengelola pembelajaran digunakan kuesioner dengan pola skala likert. Untuk mendapatkan data yang diinginkan maka instrumen harus diuji validitas dan reliabilitasnya. Uji validitas yang dilakukan mencakup uji validitas isi dan validitas butir. Uji validasi hanya diberlakukan untuk tiga instrumen, yaitu: kecerdasan emosional, kreativitas guru dan keterlibatan guru dalam MGMP. Sementara keterampilan guru mengelola pembelajaran diukur dengan APKG 1 dan APKG 2 yang telah ditetapkan oleh pemerintah sehingga tidak dilakukan uji validasi lagi.

Dalam penelitian ini digunakan metode analisis statistik inferensial dengan teknik analisis regresi ganda tiga prediktor. Berbicara tentang metode analisis data statistik, ada dua jenis yaitu metode analisis statitsik deskriptif dan metode analisis statistik induktif/inferensial. Dalam kaitan metode analisis statistik ini, Agung (2014:118) menyatakan sebagai berikut.

"Metode analisis statistik deskriptif ialah suatu cara pengolahan data yang dilakukan dengan jalan menerapkan rumus-rumus statistik deskriptif seperti: distribusi frekuensi, grafik, angka rata-rata, median, modus, mean dan standar deviasi, untuk menggambarkan suatu objek/variabel tertentu, sehingga diperoleh kesimpulan umum. Sedangkan metode analisis statistik induktif/inferensial ialah suatu cara pengolahan data yang dilakukan dengan jalan menerapkan rumus-rumus statistik inferensial untuk menguji suatu hipotesis penelitian yang diajukan peneliti, dan kesimpulan ditarik berdasarkan hasil pengujian terhadap hipotesis"

Di dalam penelitian ini menggunakan kedua metode analisis statistik tersebut. Metode analisis statistik deskriptif digunakan untuk menganalisis data dalam rangka mendeskripsikan data hasil penelitian. Dalam mendeskripsikan data hasil penelitian ini antara lain dilakukan penyajian data dalam tabel distribusi frekuensi, menghitung Modus, Media, Mean, Standar Deviasi, serta grafik. Sedangkan metode analisis statistik induktif/inferensial digunakan untuk menganalisis data hasil penelitian dalam rangka menguji hipotesis yang diajukan dalam penelitian ini. Dalam hal ini teknik analisis statistik inferensial yang digunakan adalah teknik analisis regresi ganda tiga prediktor. Dalam melakukan analisis data untuk penelitian ini ada tiga tahapan yang dilalui yakni : 1) tahap deskripsi data, 2) tahap pengujian persyaratan analisis, dan 3) tahapan pengujian hipotesis.

\section{HASIL DAN PEMBAHASAN}

Dalam hal ini disajikan hasil penelitian yang mencakup deskripsi tentang karakteristik masing-masing variabel penelitian, uraian tentang hasil pengujian persyaratan analisis, uji hipotesis, pembahasan dan implikasi penelitian. Hasil penelitian yang dimaksudkan adalah menyangkut deskripsi kecerdasan emosional guru, deskripsi kreativitas guru dan deskripsi keterlibatan guru dalam kegiatan MGMP dan deskripsi keterampilan guru mengelola pembelajaran.

Untuk mendapatkan gambaran mengenai karakteristik distribusi skor dari masingmasing variabel, berikut disajikan skor tertinggi, skor terendah, harga rerata, simpangan baku, varians, median, modus, diagram batang, dan kategorisasi masing-masing variabel yang diteliti. Untuk memudahkan mendeskripsikan masing-masing variabel.

Hasil pengukuran emosional terhadap 30 responden menunjukkan bahwa skor tertinggi yang dicapai responden adalah 127, sedangkan skor terendah yang dicapai responden adalah 95. Dan secara umum, rata-rata (mean) skor kecerdasan emosional 115,13.

Dapat diketahui bahwa sebagain besar kecerdasan emosional guru jatuh pada interval 113-118dengan frekuensi 8. Selanjutnya adalah interval 119-124 dengan frekuensi 7. Kemudian interval 101-106 dengan frekuensi 6 . Interval 107-112 dengan frekuensi 3. Terakhir adalah interval 95-100 dengan frekuensi 1.

Untuk mengetahui kecenderungan data kecerdasan emosional, penilaian acuan patokan (PAP) digunakan. Data variabel ini diukur dengan kuesioner dengan jumlah butir 30 . 
Sehingga skor maksimum ideal yang didapat oleh responden adalah 150 dan skor minimum ideal adalah 30. Sehingga, selanjutnya dapat dihitung rentangan skor untuk lima kategori sebagai berikut.

$$
\begin{aligned}
& M_{i}=\frac{\left(S_{\max }+S_{\min }\right)}{2}=\frac{(150+30)}{2}=90 \\
& S D_{i}=\frac{1}{3} M_{i}=\frac{1}{3} \times 90=30
\end{aligned}
$$

Dapat diamati bahwa guru-guru yang menilai kecerdasan emosionalnya dengan kategori tinggi sebanyak 26 orang dan kategori sedang sebanyak 4 orang. Sementara tidak ada responden yang memberi kategori Sangat tinggi, rendah dan sangat rendah (0\%). Jadi dapat disimpulkan bahwa sebagian besar guru-guru menilai kecerdasan emosionalnya tergolong tinggi dengan frekuensi 26.

Kreativitas Guru diukur dengan kuesioner yang terdiri dari 30 butir. Hasil pengukuran terhadap 30 guru menunjukkan skor tertinggi yang didapat adalah 146. Sedangkan skor terendah yang didapat adalah 108. Dan secara umum, rata-rata (mean) skor kreativitas sebesar 129,77 .

Kreatifitas guru dapat diketahui bahwa sebagian besar kreativitias guru jatuh pada interval 122-128, 129-135 dan 136-142 dengan frekuensi. Selanjutnya disusul interval 108114, 115-121 dan 143-149 dengan frekuensi 2.

Untuk mengetahui kecenderungan data kreativitas guru, penilaian acuan patokan (PAP) digunakan. Data variabel ini diukur dengan kuesioner dengan jumlah butir 30. Sehingga skor maksimum ideal yang didapat oleh responden adalah 150 dan skor minimum ideal adalah 30 .

Keterlibatan guru dalam kegiatan MGMP diukur dengan kuesioner yang terdiri dari 30 item. Hasil pengukuran terhadap 30 guru menunjukkan skor tertinggi yang didapat adalah 150, sedangkan skor terendah yang didapat adalah 98. Secara umum, nilai rata-rata (mean) keterlibatan guru dalam MGMP sebesar 118,33.

Dapat diamati bahwa ada 11 guru yang kreativitasnya terkaregori sangat tinggi dan 19 guru yang terkategori tinggi. Sementara itu, tidak ada guru yang kreativitasnya terkategori sedang, rendah, dan sangat rendah. Jadi dapat disimpulkan bahwa kreativitas guru sebagian besar termasuk ke dalam kategori tinggi dengan frekuensi 19.

Dapat diketahui bahwa keterlibatan guru dalam MGMP sebagian besar jatuh pada interval 116-124 dengan frekuensi 10. Selanjutnya disusul interval 125-133 dengan frekuensi 7, interval 107-115 dengan frekuensi 6, interval 98-106 dengan frekuensi 5 dan interval 134-142 dan 143-151 dengan frekuensi 1.

Untuk mengetahui kecenderungan data keterlibatan guru dalam kegiatan MGMP, penilaian acuan patokan (PAP) digunakan. Data variabel ini diukur dengan kuesioner dengan jumlah butir 30. Sehingga skor maksimum ideal yang didapat oleh responden adalah 150 dan skor minimum ideal adalah 30 .

Dapat diamati bahwa guru yang mengatakan terlibat dalam kegiatan MGMP dengan kategori sangat tinggi sebanyak 1 orang, kategori tinngi sebanyak 26 orang dan kategori sedang sebanyak 3 orang. Tidak ada guru yang keterlibatannya dalam MGMP terkategori rendah dan sangat rendah Jadi dapat disimpulkan bahwa sebagian besar keterlibatan guruguru dalam kegiatan MGMP terkategori tinggi dengan frekuensi 26.

Keterampilan guru mengelola pembelajaran diukur dengan APKG1 dan APKG 2 yang terdiri dari 32 butir. Hasil pengukuran terhadap 22 guru menunjukkan skor tertinggi yang didapat adalah 150. Sedangkan skor terendah yang didapat adalah 108. Nilai rata-rata (mean) keterampilan guru mengelola pembelajaran sebesar 134,77.

Dapat diketahui bahwa sebagian besar keterampilan guru mengelola pembelajaran jatuh pada interval 136-142 dengan frekuensi 11. Disusul dengan interval 135-143 dengan frekuensi 7, interval 144-152 dengan frekuensi 3, interval 143-150 frekuensi 6, interval 122-128 dan 129Jurnal Administrasi Pendidikan Indonesia | 37 
135 dengan frekuensi 5, interval 108-114 dengan frekuensi 2 dan interval 115-121 dengan interval 1.

Untuk mengetahui kecenderungan data keterampilan guru mengelola pembelajaran, penilaian acuan patokan (PAP) digunakan. Data variabel ini diukur dengan kuesioner dengan jumlah butir 32. Sehingga skor maksimum ideal yang didapat oleh responden adalah 160 dan skor minimum ideal adalah 30.

Berdasarkan uraian di atas dapat diamati bahwa keterampilan guru mengelola pembelajaran yang terkategori sangat tinggi sebanyak 6 orang, terkategori tinggi sebanyak 22 orang, dan terkategori sedang sebanyak 2 orang. Dalam peneilitian ini, tidak ada guru yang terkategori rendah dan sangat rendah. Jadi dapat disimpulkan bahwa sebagian besar kualitas pengelolaan pembelajaran tergolong ke dalam kategori tinggi dengan frekuensi 22.

Sebelum uji hipotesis dilakukan, terlebih dahulu dilakukan uji prasyarat yang lazim disebut uji asumsi klasik. Terdapat 5 uji prasyarat yang dilakukan, yaitu: uji normalitas sebaran data, uji linearitas dan keberartian arah regresi, uji multikolinearitas, uji heteroskedastisitas dan uji otokorelasi. Dengan hasil kelima uji prasyarat tersebut barulah di dapat hipotesis.

Pengujian normalitas sebaran data dilakukan dengan menggunakan uji KolmogorovSmirnov (Liliefors Significance Correction) yang dikenakan terhadap skor kecerdasan emosional, kreativitas guru, keterlibatan guru dalam MGMP dan keterampilan mengelola pembelajaran.

Nilai probalitas (Asymp. Sig. (2-tailed)) untuk semua variabel diatas 0,05 (kecerdasan emosional 0,660, Kreativitas sebesar 0,94, keterlibatan guru dalam MGMP sebesar 0,995 dan keterampilan mengelola pembelajaran sebesar 0,229). Ini berarti skor keempat variabel berdistribusi normal.

Uji linieritas garis regresi dimaksudkan untuk mengetahui keberartian koefisien arah regresi dari model linier antara variabel bebas dengan variabel terikat. Pengujian linieritas dilakukan dengan menggunakan uji F dengan bantuan program SPSS 13.0 for windows.

Hasil analisis uji linieritas garis regresi menunjukkan bahwa untuk semua hubungan variabel, harga $F$ Dev. from linierity diatas 0,05 . Dengan demikian dapat disimpulkan bahwa hubungan antara kecerdasan emosional, kreativitas guru, keterlibatan guru dalam MGMP dengan keterampilan mengelola pembelajaran mempunyai hubungan yang linier. Selanjutnya dilihat apakah koefisien arah regresi berarti atau tidak. Uji ini dilakukan untuk menaksir apakah ada hubungan yang berarti antara variabel bebas dengan variabel terikat.

Diketahui nilai probilitas linierity untuk semua pasangan variabel bebas dan terikat lebih kecil daripada 0,05. Hal ini berarti koefisien arah regresi berarti. Dengan kata lain, terdapat hubungan fungsional yang signifikan antara variabel bebas dan terikat.

Uji multikolinieritas dikenakan terhadap sesama variabel bebas yaitu skor kecerdasan emosional, kreativitas guru, keterlibatan guru dalam MGMP dan keterampilan mengelola pembelajaran. Untuk pengujian ini digunakan korelasi product moment antara sesama variabel bebas dengan memprediksi nilai VIF (variance inflation factor). Jika harga VIF $<10$ maka antara sesama variabel bebas tidak kolinier (Candiasa, 2010).

Terlihat bahwa nilai VIF antara variabel kecerdasan emosional dengan keterampilan guru mengelola pembelajaran adalah 2,502, Kreativitas dengan keterampilan guru mengelola pembelajaran adalah 2,009, dan keterlibatan guru dalam MGMP dengan keterampilan guru mengelola pembelajaran adalah 2,151. Kesemua nilai tersebut di bawah 10. Hal ini berarti data bebas dari gejala multikolinearitas dan memenuhi uji prasyarat analisis.

Uji Teknik yang digunakan untuk mencari heteroskedastisitas adalah dengan menggunakan modul regression linier pada program SPSS 13.0 for windows. Kriteria keputusan adalah: (1) jika ada pola tertentu, seperti titik membentuk suatu pola tertentu yang teratur maka telah terjadi heteroskedastisitas, (2) jika tidak ada pola yang jelas, serta titik-titik menyebar secara acak hal ini berarti tidak terjadi heteroskedastisitas.

Dari semua scatterplot di atas terlihat kebanyakan titik menyebar merata baik di atas maupun di bawah sumbu X. dan tidak ditemukan suatu pola yang jelas dari titik-titik yang Jurnal Administrasi Pendidikan Indonesia | 38 
mengelompok. Jadi dapat disimpulkan bahwa data bebas dari gejala heteroskedastisitas dan memenuhi uji prasyarat analisis.

Seperti dinyatakan sebelumnya, uji autokorelasi menggunakan rumus Durbin-Watson. Perhitungan dilakukan dengan SPSS 16 for windows. Pada hasil penghitungan, didapat nilai $\mathrm{d}=1,767$. Untuk responden 30 dan variabel bebas 3 , didapat nilai $\mathrm{d}_{\mathrm{u}}=1,6498$ pada taraf kesalahan 0,05. Berdasarkan kriteria yang ditentukan dimana nilai $d_{u}<\mathrm{d}<4-d_{U}$ $(1,6498<1,767<2,233)$ maka data bebas dari gejala autokorelasi. Sehingga uji hipotesis bisa dilanjutkan (Lihat uji prasyarat selengkapnya pada Lampiran 5 halaman 177).

Setelah uji prasyarat terpenuhi maka akan dilanjutkan dengan uji hipotesis untuk menjawab permasalahan penelitian. Hipotesis yang diuji dalam penelitian ini adalah: (1) terdapat kontribusi yang signifikan kecerdasan emosional terhadap keterampilan mengelola pembelajaran, (2) terdapat kontribusi yang signifikan kreativitas terhadap keterampilan mengelola pembelajaran, (3) terdapat kontribusi yang signifikan keterlibatan guru dalam MGMP terhadap keterampilan mengelola pembelajaran, dan (4) secara bersama-sama, terdapat terdapat kontribusi yang signifikan kecerdasan emosional, kreativitas dan keterlibatan guru dalam MGMP terhadap keterampilan mengelola pembelajaran.

Hipotesis pertama menyatakan bahwa terdapat kontribusi yang signifikan kecerdasan emosional terhadap keterampilan mengelola pembelajaran Bahasa Indonesia. Untuk menguji hipotesis ini digunakan teknik regresi linier sederhana, korelasi, dan analisis kontribusi.

Hipotesis kedua menyatakan bahwa terdapat kontribusi yang signifikan kreativitas guru terhadap keterampilan guru mengelola pembelajaran. Untuk menguji hipotesis ini digunakan teknik regresi linier sederhana, korelasi, dan analisis kontribusi.

Hipotesis ketiga menyatakan bahwa terdapat korelasi yang signifikan antara keterlibatan guru dalam MGMP dengan keterampilan mengelola pembelajaran bahasa Indonesia. Untuk menguji hipotesis ini juga digunakan teknik regresi linier sederhana, korelasi, dan analisis kontribusi.

Hipotesis keempat menyatakan bahwa secara bersama-sama, terdapat kontribusi yang signifikan kecerdasan emosional, kreativitas guru dan keterlibatan guru dalam MGMP secara bersama-sama terhadap keterampilan mengelola pembelajaran bahasa Indonesia. Untuk menguji hipotesis ini digunakan teknik regresi ganda. Hasil perhitungan regresi ganda diperoleh

persamaan regresi $\hat{Y}=15,332+0,066 X_{1}+0,673 X_{2}+0,206 X_{3}$ dengan $F_{\text {reg }}=17,148$ dengan probabilitas (p) 0.000 (selengkapnya dapat dilihat pada lampiran ). Karena nilai $p<0,000$ maka regresi dapat dipakai untuk memprediksi kecerdasan emosional, kreativitas guru dan keterlibatan guru dalam MGMP secara bersama-sama terhadap keterampilan mengelola pembelajaran bahasa Indonesia pada taraf kepercayaan $95 \%$.

Berdasarkan pengujian hipotesis diperoleh bahwa terdapat kontribusi yang signifikan kecerdasan emosional terhadap keterampilan mengelola pembelajaran bahasa Indonesia melalui persamaan garis regresi $\hat{\mathrm{Y}}=45,510+0,775 \mathrm{X}_{1}$ dengan $\mathrm{t}_{\text {-hiting }}=4,339$ dengan nilai probabilitas (p) $0.00(p<0,05)$. Dalam penelitian ini ditemukan korelasi positif yang signifikan antara kecerdasan emosional dengan keterampilan mengelola pembelajaran bahasa Indonesia sebesar 0,634 dengan besar kontribusi 40,2\%. Hal ini berarti semakin tinggi kecerdasan emosional guru, semakin tinggi pula keterampilan mengelola pembelajaran bahasa Indonesia. Ini dapat dijadikan suatu indikasi bahwa kecerdasan emosional dapat dipakai sebagai prediktor keterampilan mengelola pembelajaran bahasa Indonesia atau dengan kata lain bahwa kecerdasan emosional berfungsi determinan terhadap keterampilan mengelola pembelajaran bahasa Indonesia. Sumbangan efektif (SE) variabel kecerdasan emosional terhadap keterampilan mengelola pembelajaran bahasa Indonesia sebesar 3,2\%.

Kecerdasan emosional berkaitan erat dengan kemampuan memotivasi diri sendiri, mengatasi frustasi, mengontrol desakan hati, mengatur suasana hati (mood), berempati serta kemampuan bekerja sama. Kecerdasan emosional yang baik tentunya akan membawa dampak yang bagus terhadap individu karena mereka cenderung memiliki keadaan yang lebih stabil dan mampu mengelola emosinya dengan baik. Menurut Suparno (2004), kecerdasan 
emosional orang dapat dilihat dari tingkah laku yang ditunjukannya sehari-hari. Kecerdasan emosional yang baik akan tercermin dari psikologis yang kuat menerima perubahan dan mengubah kondisi hidup yang tidak menyenangkan menjadi menyenangkan.

Jika dihubungkan dengan konteks pendidik, guru yang memiliki kecerdasan emosional yang tinggi sangat berpeluang memiliki kepribadian yang cerdas. Guru tersebut akan mampu memotivasi dirinya untuk menjadi lebih baik, bisa mengatasi permasalahan yang berhubungan dengan profesinya sebagai guru, mampu mengontrol suasana hatiyang yang gelisah saat mengajar, dan mampu bekerja dengan teman-temannya. Disamping itu, guru yang memiliki kecerdasan tinggi tentu akan lebih adaptif dengan perubahan jaman.

Berdasarkan pengujian hipotesis diperoleh bahwa terdapat kontribusi yang signifikan antara kreativitas guru terhadap keterampilan mengelola pembelajaran bahasa Indonesia melalui persamaan garis regresi $\hat{\mathrm{Y}}=21,721+0,869 \mathrm{X}_{2}$ dengan $\mathrm{t}_{\text {-hitung }}=6,802$ dengan nilai probabilitas (p) $0.001(p<0,05)$. Dalam penelitian ini ditemukan korelasi positif yang signifikan antara kreativitas guru dengan keterampilan mengelola pembelajaran bahasa Indonesia sebesar 0,789 dengan besar kontribusi $62,3 \%$. Hal ini berarti makin tinggi nilai kreativitas guru, makin tinggi pula keterampilan mengelola pembelajaran bahasa Indonesia. Ini dapat dijadikan suatu indikasi bahwa kreativitas guru dapat dipakai sebagai prediktor keterampilan mengelola pembelajaran bahasa Indonesia atau dengan kata lain bahwa kreativitas guru berfungsi determinan terhadap keterampilan mengelola pembelajaran bahasa Indonesia. Sumbangan efektif (SE) variabel kreativitas guru terhadap keterampilan mengelola pembelajaran bahasa Indonesia sebesar $45,4 \%$.

Kreativitas yang sangat dibutuhkan lainya adalah rasa ingin tahu dan terbuka. Guru yang memiliki rasa ingin tahu pasti memiliki sifat yang peka, baik peka terhadap perubahan jaman, kebutuhan siswa, karakter peserta didik dan lainnya. Kreativitas itulah yang akan mengarahkan guru merencanakan dan melaksanakan pengelolaan pembelajaran yang baik. Di sini, guru akan mencoba hal-hal yang baru atau mengkombinasikan hal-hal baru sebagaimana yang diterangkan oleh Haefele (1962) dalam Munandar, 1999; yang menyatakan kreativitas adalah kemampuan untuk membuat kombinasi-kombinasi baru yang mempunyai makna sosial. Di sini, guru bisa mengutak atik atau mengkombinasikan berbagai metode pembelajaran dengan pendekatan penilaian atau yang lainya agar kelas menjadi lebih menrik bagi siswa.

Berdasarkan pengujian hipotesis diperoleh bahwa terdapat kontribusi yang signifikan antara keterlibatan guru dalam MGMP terhadap keterampilan mengelola pembelajaran bahasa Indonesia melalui persamaan garis regresi $\hat{Y}=66,397+0,578 X_{3}$ dan nilai t-hitung sebesar 4,460 dengan nilai probabilitas (p) $0.00(p<0,05)$. Dalam penelitian ini ditemukan korelasi positif yang signifikan antara keterlibatan guru dalam MGMP dengan keterampilan mengelola pembelajaran bahasa Indonesia sebesar 0,644 dengan besar kontribusi 41,5\%. Hal ini berarti makin tinggi keterlibatan guru dalam MGMP guru, makin tinggi pula keterampilan mengelola pembelajaran bahasa Indonesia. Ini dapat dijadikan suatu indikasi bahwa keterlibatan guru dalam MGMP dapat dipakai sebagai prediktor keterampilan mengelola pembelajaran bahasa Indonesia atau dengan kata lain bahwa keterlibatan guru dalam MGMP guru berfungsi determinan terhadap keterampilan mengelola pembelajaran bahasa Indonesia. Sumbangan efektif (SE) variabel keterlibatan guru dalam MGMP terhadap keterampilan mengelola pembelajaran bahasa Indonesia sebesar $22,2 \%$.

Terakhir, melalui MGMP guru akan aktif dalam mengembangkan metode pembelajaran yang sesuai, menarik dan menyenangkan. Hal ini merupakan kunci utama dari keterampilan guru mengelola pembelajaran. Melalui pertemuan dengan sesama guru ata pelajaran, guru akan belajar mengembangkan dan menerapkan metode pembelajaran yang menyenangkan yang mampu membuat proses belajar mengajar menjadi kondusif. Dengan kata lain, keterampilan guru dalam mengelola pembelajaran secara otomatis akan dilatih dan dikembangkan.

Temuan ini didukung oleh Sunarsa (2013). Hasil penelitian ini menunjukan bahwa terdapat kontribusi intensitas keterlibatan guru pada kegiatan MGMP terhadap kinerja guru 
matematika SMA Negeri Kabupaten Tabanan sebesar 6,30\%. Analisis lebih lanjut menunjukan bahwa keterlibatan guru dalam kegiatan MGMP menyumbang 9,50\%.

Secara khusus dalam mengelola proses pembelajaran, peran kecerdasan emosional guru sangat diperlukan. Mengelola pembelajaran adalah pekerjaan utama seorang guru dan membutuhkan kecerdasan dan pengetahuan yang kompleks. Mengelola pembelajaran mencakup merencanakan pembelajaran dan melaksanakan rencana tersebut. Ada banyak hal yang mesti dipertimbangkan dan dilaksanakan. Terlebih proses pembelajaran harus sesuai dengan perkembangan jaman.

Hasil analisis menunjukkan bahwa, secara bersama-sama terdapat kontribusi yang signifikan antara kecerdasan emosional, kreativitas, dan keterlibatan guru dalam MGMP terhadap keterampilan mengelola pembelajaran bahasa Indonesia melalui persamaan garis regresi $\hat{Y}=15,332+0,066 X_{1}+0,673 X_{2}+0,206 X_{3}$ dengan $F_{\text {reg }}=17,148$ dengan probabilitas (p) 0.000 (selengkapnya dapat dilihat pada lampiran). Ketiga variable tersebut memiliki nilai korelasi sebesar 0,815 terhadap keterampilan mengelola pembelajaran guru dengan kontribusi sebesar $62,6 \%$.

\section{PENUTUP}

Data yang dikumpulkan kemudian dianalisis secara statistik. Ada tiga tahap analisis yang dilakukan yaitu: tahap deskripsi data, tahap pengujian prasyarat dan tahap pengujian hipotesis. Hasil dari penelitian ini adalah (1) terdapat kontribusi yang signifikan kecerdasan emosional terhadap keterampilan mengelola pembelajaran guru melalui persamaan garis regresi $\hat{\mathrm{Y}}=45,510+0,775 \mathrm{X}_{1}$ dengan kontribusi sebesar $40,2 \%$. dan sumbangan efektif sebesar 3,2\%, (2) terdapat kontribusi yang signifikan kreativitas guru terhadap keterampilan mengelola pembelajaran guru melalui persamaan garis regresi: $\hat{Y}=21,721+0,869 X_{2}$ dengan kontribusi sebesar $62,3 \%$ dan sumbangan efektif sebesar $45,4 \%$, (3) terdapat kontribusi yang signifikan keterlibatan guru dalam MGMP guru terhadap keterampilan mengelola pembelajaran guru melalui persamaan garis regresi $\hat{Y}=66,397+0,578 X_{3}$ dengan kontribusi sebesar $41,5 \%$ atau sumbangan efektif sebesar $14 \%$, dan (4) secara bersama-sama terdapat kontribusi yang signifikan kecerdasan emosional, kreativitas guru, dan keterlibatan guru dalam MGMP terhadap keterampilan mengelola pembelajaran guru melalui persamaan garis regresi $\hat{Y}=$ $15,332+0,066 X_{1}+0,673 X_{2}+0,206 X_{3}$ dengan kontribusi sebesar $62,6 \%$.

Berdasarkan analisis data seperti yang telah dideskripsikan, ditemukan berberapa hal sebagai berikut.

(1) Terdapat kontribusi yang signifikan kecerdasan emosional terhadap keterampilan mengelola pembelajaran guru melalui persamaan garis regresi $\hat{Y}=45,510+0,775 X_{1}$ dengan kontribusi sebesar $40,2 \%$. dan sumbangan efektif sebesar $3,2 \%$.

(2) Terdapat kontribusi yang signifikan kreativitas guru terhadap keterampilan mengelola pembelajaran guru melalui persamaan garis regresi: $\hat{\mathrm{Y}}=21,721+0,869 \mathrm{X}_{2}$ dengan kontribusi sebesar $62,3 \%$ dan sumbangan efektif sebesar $45,4 \%$.

(3) Terdapat kontribusi yang signifikan keterlibatan guru dalam MGMP guru terhadap keterampilan mengelola pembelajaran guru melalui persamaan garis regresi $\hat{\mathrm{Y}}=$ $66,397+0,578 X_{3}$ dengan kontribusi sebesar $41,5 \%$ atau sumbangan efektif sebesar $14 \%$.

(4) secara bersama-sama terdapat kontribusi yang signifikan kecerdasan emosional, kreativitas guru, dan keterlibatan guru dalam MGMP terhadap keterampilan mengelola pembelajaran guru melalui persamaan garis regresi $\hat{Y}=15,332+0,066 X_{1}+0,673 X_{2}+$ $0,206 X_{3}$ dengan kontribusi sebesar $62,6 \%$.

Berdasarkan temuan tersebut dapat disimpulkan bahwa secara terpisah maupun simultan, terdapat kontribusi yang signifikan antara kecerdasan emosional, kreativitas guru, dan 
keterlibatan guru dalam MGMP guru terhadap keterampilan mengelola pembelajaran guru-guru bahasa Indonesia se-Kabupaten Badung. Dengan demikian ketiga faktor tersebut dapat dijadikan prediktor atau determinan tingkat kecenderungan keterampilan mengelola pembelajaran guru-guru bahasa Indonesia se-Kabupaten Badung.

\section{DAFTAR RUJUKAN}

Depdiknas. 2001a. Manajemen Peningkatan Mutu Berbasis Sekolah: Panduan Monitoring dan Evaluasi. Jakarta: Dirjen Dikdasmen.

Fattah, Nanang.. 2004. Konsep Manajemen Berbasis Sekolah (MBS) dan Dewan Sekolah. Bandung:CV.Pustaka Bani Quraisy.

Guilford, J.P. 1950. Fundamental Statistic in Psychology and Education. Tokyo: Kogakusha Company, Ltd.

Hadi, Sutrisno. 1997. Seri Program Statistik Manual SPS Paket Midi. Yogyakarta : Universitas Gadjah Mada.

Hamzah B. Uno, dkk. 2001. Pengembangan Instrumen untuk Penelitian. Jakarta : Dilema Press.

Hawadi, Reni Akbar dkk. 2001. Kreativitas. Jakarta: Gramedia Pustaka Utama.

Poerwadarminto. 2003. Kamus Umum Bahasa Indonesia. Solo: PT.Tiga Serangkai Pustaka Mandiri.

Purwanto, M.Ngalim.1993. Administrasi dan Supervisi Pendidikan. Bandung: PT. Remaja Rosdakarya.

Purwanto, Budi. 2004. Fisika Dasar Teori dan Implementasinya. Solo : PT Tiga Serangkai Pustaka Mandiri.

Rusman. 2011. Model-model pembelajaran-Mengembangkan Profesionalisme Guru. Cetakan keempat. Jakarta: PT.Rajagrafindo Persada.

Suarya, I Ketut. 2015. Determinasi Kemampuan Profesional, Etos Kerja, dan Kecerdasan Emosional terhadap Kinerja Guru SD Tersertifikasi pada Gugus I dan II Kecamatan Abang. E-journal Pasca Sarjana Undiksha

Sudjana. 1996. Metoda Statistika Edisi 6. Bandung : Tarsito.

Samani, Muchlas. 2007. Menjadi Guru Profesional dalam Perpektif Undang-Undang Guru dan Dosen. Surabaya: Universitas negeru Surabaya.

Suarya, I Ketut. 2015. Determinasi Kemampuan Profesional, Etos Kerja, dan Kecerdasan Emosional terhadap Kinerja Guru SD Tersertifikasi pada Gugus I dan II Kecamatan Abang. E-journal Pasca Sarjana Undiksha

Surasmini, Ni Wayan. 2008. "Studi Evaluatif Tentang Pelaksanaan Program Blockgrant KKG/MGMP di Provinsi Bali”. Tesis. Singaraja: Program Pascasarjana Universitas Pendidikan Ganesha.

Trianto and Tutik, Titik Triwulan. 2007. Sertifikasi Guru dan Upaya Peningkatan Kualifikasi, Kompetensi dan Kesejahteraan. Jakarta: Prestasi Pustaka. 
Waluyo, Edi. 2013. Pengaruh Kreativitas Guru dan Motivasi Belajar Siswa Terhadap Hasil Belajar Siswa Kompetensi Keahlian Administrasi Perkantoran di SMK Muhammadiyah 2 Moyudan Sleman. Skripsi: Universitas Negeri Yogyakarta. Tersedia pada http://eprints.uny.ac.id/16932/1/PDF SKRIPSI.pdf Diakses pada tanggal 17 Desember 2015. 